\title{
Analysis of the possibility of employing 3D printing technology in crisis situations
}

\author{
Andrzej Wysoczański \\ wysoczanski@witi.wroc.pl | (D) https://orcid.org/0000-0001-7095-2283 \\ Department of Engineer Equipment, Bridging and Crossing Systems, \\ Military Institute of Engineer Technology \\ Zbigniew Kamyk \\ kamyk@witi.wroc.pl | (D) https://orcid.org/0000-0003-4200-5996 \\ Department of Engineer Equipment, Bridging and Crossing Systems, \\ Military Institute of Engineer Technology \\ Yann Yvinec \\ yann.yvinec@mil.be | (D) https://orcid.org/0000-0002-3054-5699 \\ Department of Communication, Information, Systems and Sensors (CISS), \\ Royal Military Academy, Brussels, Belgium
}

\begin{abstract}
Scientific Editor: Stanistaw Kuciel, Cracow University of Technology

Technical Editor: Aleksandra Urzędowska, Cracow University of Technology Press

Language Editor: Timothy Churcher, Merlin Language Services

Typesetting: Matgorzata Murat-Drożyńska, Cracow University of Technology Press
\end{abstract}

Received: April 7, 2021

Accepted: June 17, 2021

Copyright: ๑ 2021 Wysoczański, Kamyk, Yvinec. This is an open access article distributed under the terms of the Creative Commons Attribution License, which permits unrestricted use, distribution, and reproduction in any medium, provided the original author and source are credited.

Data Availability Statement: All relevant data are within the paper and its Supporting Information files.

Competing interests: The authors have declared that no competing interests exist.

Citation: Wysoczański, A., Kamyk, Z., Yvinec, Y. (2021). Analysis of the possibility of employing 3D printing technology in crisis situations. Technical Transactions, e2021008. https://doi.org/10.37705/ TechTrans/e2021008

\begin{abstract}
Events related to climate change and the increase in the occurrence of natural disasters, as well as the increasing incidence of new diseases, have all caused the prominence of regional security and crisis management around the world to rise. Three-dimensional printing, which has seen noteworthy developed in recent years, both in terms of print parameters, and the magnitude of the production potential, may prove helpful in this matter. Enormous opportunities have arisen which, if properly directed, can save human life and preserve health in crisis situations, when traditional supply chains could be disrupted or even prevented. The use of additive technologies, however, has its limitations and in order to be able to take full advantage of the opportunities they offer, a legitimate functional system should be created and embedded within proper structures to support crisis management. This paper presents the advantages and disadvantages of using 3D printers and the possibility of their implementation as part of the current crisis-response systems. The article proposes a model for incorporating additive technologies into the crisismanagement system.
\end{abstract}

Keywords: 3D printing, 3D farms, distributed manufacturing, additive technologies, CoVID-19 


\section{Introduction}

Just two decades ago, the market for 3D printers practically did not exist, not to mention that of personal devices, available to everyone (Raport Deloitte, 2020). Additive manufacturing technologies, also known as 3D printing technologies, were originally created as specialised tools for rapid prototyping, accessible only to a few. However, they were quickly adapted to other areas of our lives. The concept of a RepRap machine, e.g. a self-replicating machine, as well as the development of devices and open-source software capable of being easily modified opened the way for thousands of inventors around the world to improve their own ideas and played a significant role in popularising 3D printers. The dynamic development of this field shows that the prospects for using 3D printers are practically unlimited, as they have become a permanent feature of mechanical (Krishnaswamy, et al. 2020) and biomedical engineering (Levin et al. 2020, Kashte, Maras, Kadam 2018). 3D printers have also gradually begun to compete in the food market, as they can be designed with the capability of creating food of any texture, taste or nutritional content (Sun et al. 2018), or help conquer space, where spare parts production has been initiated a while ago (Made in Space, 2020). The number of available additive machine models and their potential is constantly expanding, as is the number of printing technologies, each with their own specific application. The most commonly used technologies for the manufacture of functional mechanical parts are fused deposition modelling (FDM) and selective laser sintering (SLS) (Salmi, et al. 2020). This is mainly due to high availability (3D Printing Market Size, Share \& Trends Analysis Report, 2020), low printing costs (Krishnaswamy, et al. 2020), and both the ease of obtaining consumables and their high variety. Due to these reasons, two technologies have been selected as the subject of analysis in this paper.

Currently, it is estimated that in 2019, the value of the world market for 3D printers amounted to $\$ 11.6$ billion (3D Printing Market Size, Share \& Trends Analysis Report, 2020). The manufacturing industry has also found application for this type of printer as many companies implement additive manufacturing technologies, replacing traditional solutions (Raport Deloitte, 2020). This creates a huge potential which, if properly directed, would be able to save human life and preserve health in extraordinary situations. This is of particular importance because crisis situations - understood as "situations adversely affecting the level of safety of people, of large properties or assets or of the natural environment, causing significant limitations in the operation of competent public administrative bodies due to the inadequacy of the resources and means available" (Dz. U. 2007 nr 89 poz. 590, Erbeyoglu, Gökalp, Bilge, 2020) - occur more and more often, affecting an increasingly high number of people (Farahani, et al. 2020). A properly designed system for the use of 3D printing would provide vital support in crisis response efforts, which are currently based mainly on strategic reserves (Erbeyoglu, Gökalp, Bilge, 2020).

One of the key factors in an effective response to a crisis situation is having an appropriate stock of materials (Dz. U. 2007 nr 89 poz. 590, Erbeyoglu, Gökalp, Bilge, 2020) as well as production capacities capable of satisfying swiftly and rapidly growing needs. However, even highly-developed countries are unable to store the necessary amount of strategic reserves, which is essential in a global crisis, when the opportunity to purchase products is curtailed (Salmi, et al. 2020). One of the reasons behind this is the necessity to incur storage costs, as well as the aging of inventories, which should be rotated (Cloudhury, Saha, Das, 2011). In addition, it is not always possible to accurately assess the magnitude of the crisis, and thus to determine the requisite amount of material reserves, as their planning takes place cyclically every few years, mainly on the basis of the analysis of past incidents and current needs.

The obvious support with regard to strategic reserves are the capabilities of the given country's industry, although in the case of traditional production of components or machines, altering the production line is associated with an 
enormous financial burden and a considerable amount of labour. A good example of such activities is the production of respirators by the Ford Motor Company in cooperation with General Electric's healthcare unit during the COVID-19 epidemic, where it took nearly a month to adapt factories to the new product (Interview with Ford Motor Company CEO for Reuters 2020).

Another factor affecting production capacity is the restriction of the movement of people and goods due to the limitations imposed to counteract crisis situations, which can also result in downtime for many companies, limiting production capacity. Such constraints may be the result of extraordinary circumstances, such as the closure of borders due to a pandemic, or paralysing European air traffic due to eruption of an Icelandic volcano in the 2010 (Budd, et al. 2011).

\section{Advantages and drawbacks of the use of 3D printing}

The solution to the aforementioned problems may be the use of threedimensional printing technology. Compared to traditional manufacturing processes, such as the use of an injection moulder, which injects hot plastic into a die, thus shaping a given element, 3D printers deposit the heated material layer by layer, as in the case of fused filament fabrication (FFF), also known as fused deposition modelling (FDM) technology, or bind a layer of fine powder using a laser beam, like in case of selective laser sintering (SLS) machines (Salmi, et al. 2020). The unquestionable advantage of additive manufacturing is its versatility, as during a single printing operation, printers are capable of producing several different elements, or even entire working mechanisms, without the need to change special attachments, and with no limitations related to the use of dies, the use of adhesives or the dimensions of welds (Salmi, et al. 2020).

It is worth noting here that in order to produce even the most specialised elements or devices, only basic skills for using a given additive manufacturing machine are needed. The focus is mainly on replenishing consumable materials, manufacturing control and simple post-production processing, limited to removing unsintered powder or dissolving additional supporting materials. Understandably, this is assuming that the person printing has at their disposal a print-ready model in a *.gcode file format or in any other format supported by the printer. This significantly reduces the required qualifications of employees needed to produce various parts, and should those employees be absent, by reason of the epidemiological quarantine or movement restrictions, such an absence would not result in a complete stoppage of production. This is due to the fact that training of new personnel is for most printers, a matter of a few hours at most. With regard to the earlier example of respirator production, the following projects should be mentioned here: the Spanish "Leitat 1" (LEITIAT, 2020), the American "ARMEE" (ARMEE, 2020) or the Polish "VantilAid” (VentilAid, 2020), which resulted in an almost fully printable device capable of saving lives, when certified medical equipment was unavailable, and which could be manufactured anywhere, the only condition being access to a 3D printer.

Using additive manufacturing technologies leads to a reduction of the need to store a large variety of items to a much smaller amount of raw materials necessary for production, such as filaments or polymer and metal powders or resins. This considerably facilitates resource management, and simplifies logistics and the handling of deliveries. An example of the impact of 3D printing on the reduction of logistics costs is the implementation of water purification systems (filters) in areas with underdeveloped local infrastructure. Instead of sending ready-made filters, which mostly consist of empty reaction chambers, the shipment of the filter medium itself (e.g. in the form of ion-conducting membranes) (Bogdanowicz, et al. 2018) could be organised, whereas the filter housings could be manufactured in-situ. A standard 3D printer filament made of polylactide (PLA) with a diameter of $1.75 \mathrm{~mm}$, weighing about $1 \mathrm{~kg}$ and with a volume of $0.0018 \mathrm{~m}^{3}$ is enough to manufacture a cylinder with a wall thickness 


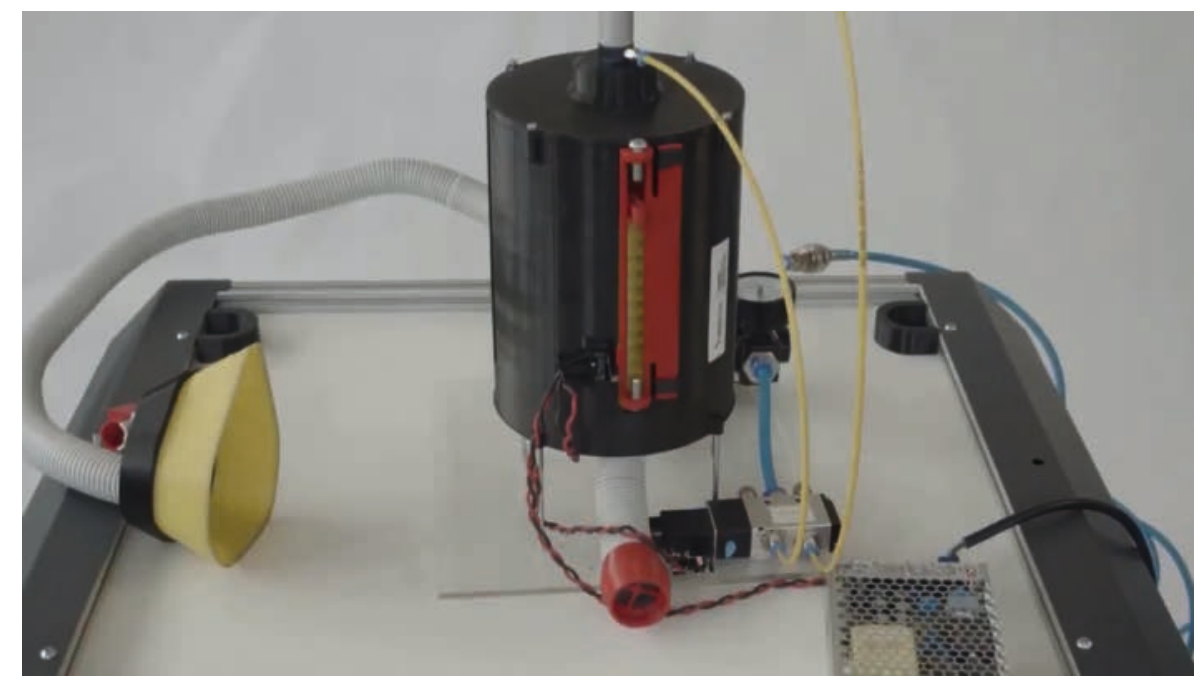

of $5 \mathrm{~mm}$ and a volume of around $0.1 \mathrm{~m}^{3}$. This saves transport space and, in turn, cuts the cost of such a filter, especially in terms of intercontinental transport. Additionally, the materials used for printing are very resistant to changing storage conditions, and the only "threat" to the stored raw materials is humidity in the atmosphere, which significantly reduces the quality of the printout, or may even prevent it (Kim, et al. 2016). However, consumable materials which are vacuum-packed with a moisture absorbent can be stored practically without restrictions resulting from the need for maintenance and service or time restrictions. This further reduces the workload required to maintain the desired level of strategic reserves.

Another pivotal factor is the price of the adopted solution. In this area, 3D printers seem to be a very favourable option due to the ratio of the production costs to the number of manufactured elements. In contrast to traditional industry, where the complexity of parts and the assumed production volume affect the price of the finished product, in 3D printing, the production costs remain essentially unchanged and depend solely on the weight of the printed element (Fernandez-Vicente et al. 2017, Minguella-Canela et al. 2018). It is also worth mentioning that there exists the possibility of reusing raw materials, should too many elements be produced, or after the crisis is over, as there are machines capable of processing the used plastics back into filaments or powders (Tian, et al. 2017).

The unquestionable advantage of 3D printers over traditional production is also the high portability of the devices in question. To start full-scale production, equipment used in additive manufacturing calls for two elements only: connection to a power source and protection against external conditions. This enables the relocation of entire production plants to outside of the endangered area and the resumption of production in a very short period of time.

The above-mentioned requirement for connection to a stable power source is also the most significant disadvantage in the use of 3D technology, as in the case of limitations in the power supply, printer operation is difficult or near impossible. Understandably, such devices could be powered using power generators, but due to the relatively large number of printers used, it is a very ineffective and costly solution. Additionally, additive manufacturing machines are very sensitive to the shape of the signal and the value of the input current, and in particular, to the approximate sine (the so-called modified sine wave) generated by lower quality generating sets. Such a power supply may result, for example, in the incorrect operation of stepper motors or disturb the logic voltage of the control systems causing a number of problems, from lowering the print quality to the utter destruction of the printer itself (Wimpenny, et al. 2017). Machines that are currently available on the market are equipped with pulse power supplies, which are able to provide a stable operating voltage even in such conditions. However,
Fig. 1. MK I - VentilAid Last Resort Venitlator Copyright permission from VentilAid, Source: VentilAid (online) 
by using photovoltaic panels, there is the potential to remove the need to use generators and decrease production costs (Bogdanowicz, et al. 2020).

Another key factor which should be taken into account when discussing 3D printing is the material used to print and its limitations. The general rule is that the stronger the material, the more complicated the printing process and therefore the more expensive the printing. Polylactide (PLA) can serve as an example of an inexpensive material here. It can be used in virtually any printer; it is about ten times cheaper than nylon, which requires a heated bed, an enclosed work space and higher heating block temperatures. In return, however, an increase in the strength of the material is obtained, for example, the modulus of elasticity for PLA is approx. 5.6 GPa, whereas for nylon, it is $23.3 \mathrm{GPa}$. The same goes for the softening temperature, which is approximately $60^{\circ} \mathrm{C}$ and $220^{\circ} \mathrm{C}$, respectively (Snopczyński, Kotliński, Musiałek 2019).

The biggest drawback of using additive technologies is the time needed for printing. An element which takes the injection moulder a few seconds to produce may even take several hours to print. This situation is not improved by the fact that the printers require a much shorter preparation time than traditional industry machines does. The only possibility to compensate for this disadvantage is to increase the number of printers working simultaneously.

\section{Proposed applications of additive manufacturing in crisis management}

The implementation of three-dimensional printing into a crisis management system should utilise the experience gained during the development of this particular technology. One of solutions put forward is the use of printers based on two modes, namely distributed manufacturing or 3D print farms, also known as print cells. Both forms of manufacturing have their advantages but also limitations, particularly in terms of their responsiveness to crisis situations.

Distributed manufacturing is a very obvious model for using 3D printers, especially for personal use, based mainly on FDM technology. In 2015, according to data by Deloitte (Raport Deloitte, 2020), there were over 659,000 3D printers all over the world, and each of them, from large industrial machines to small devices used by enthusiasts, could become a factory for the desired elements. A public campaign called "3D Printers for Hospitals" (Polish: "DrukarzeDlaSzpitali" - Akcja Drukarze Dla Szpitali, 2020) can serve as an illustration of how such distributed manufacturing potential is currently utilised. As part of the campaign, each person who had a 3D printer at their disposal, having registered on the website in order for the printing to be coordinated, could start the manufacturing of face shields or any other type of equipment. Those, in turn, were delivered to people in need, hospitals or other institutions by volunteers. This solution is extremely resistant to disruptions resulting from restrictions imposed in the wake of a crisis, it also reduces the labour and costs associated with the transport of goods, as those goods are manufactured directly where they are needed. Nevertheless, this particular form of distribution and decentralisation definitely increases the reaction time to a given phenomenon and largely depends on the good will and willingness of a vast number of people to cooperate. Obviously, there exist mechanisms which could encourage volunteers to help, such as treating the produced items as donations benefiting national security, the value of which could be deducted from their taxes. Another significant disadvantage is leaving control over the quality of the manufactured elements to the manufacturers, who may not have the appropriate competences, as this may result in unreliability of components or machines on which someone's life may depend.

Another approach, which is more centralised and thus more appropriate for state institutions who are responsible for crisis response, is to set up 3D print farms, i.e. production halls filled with 3D printers adapted for the mass production of parts and components. Such installations run by private companies 
already exist and benefit human life and health. Prusa Research company (Prusa Research, 2020), which has a farm consisting of 500 FDM 3D printers, has joined the fight against COVID-19 by producing face shields for Czech healthcare service workers may serve as an example here. In this case, response time was a key factor. The team lead by Josef Prusa needed three days to create their solution, produce a prototype and get it approved. The production itself could start right after that. The production capacity was around 4,000 shields per day and the cost of producing each was estimated to be less than $\$ 1$. Obviously, should a similar crisis situation arise again, the time needed to react would be shortened by the lack of a need draw the design - manufacturing of the required elements could be initiated immediately. With good organisation and the use of modern technologies, such companies achieve a very high level of automation, where a minimum number of staff is sufficient to operate hundreds of devices, and this reduces costs and the risk of downtime caused by the human factor.

Another advantage of such a solution is full control over the quality and volume of production as well as over the materials used for this purpose, which is particularly important in the case of manufacturing highly specialised elements. An unquestionable benefit of printing farms is also the possibility of making their manufacturing potential, owned by public institutions, available to private entities. Profits generated in this way could be used to support the operation of the entire crisis management system. Unfortunately, such a solution, due to its fixed location, is very susceptible to the impact of external factors, such as power outage, flooding, or the need to leave the area where a 3D farm is located should toxic industrial compounds be released.

Additive manufacturing techniques, despite their current limitations, are a great tool to support a crisis management system and, in particular, to maintain and supplement reserve stocks but not to replace them. Such a system should be based on four pillars:

- strategic reserves, the task of which is to maintain stocks of non-printable equipment, printable equipment for immediate deployment, as well as energy resources and food supplies;

- printing farms, both state-owned and private institutions, onto which services in kind and personnel would be imposed, bearing the burden of manufacturing necessary goods in case of a prolonged crisis;

- an internet platform for managing distributed manufacturing, the main goal of which would be to effectively use the potential of volunteers and not only personal 3D printers but also of other computer numerically controlled (CNC) devices;

- project teams with a database of projects and solutions, containing ready-made production plans for specific equipment with the required testing and qualification.

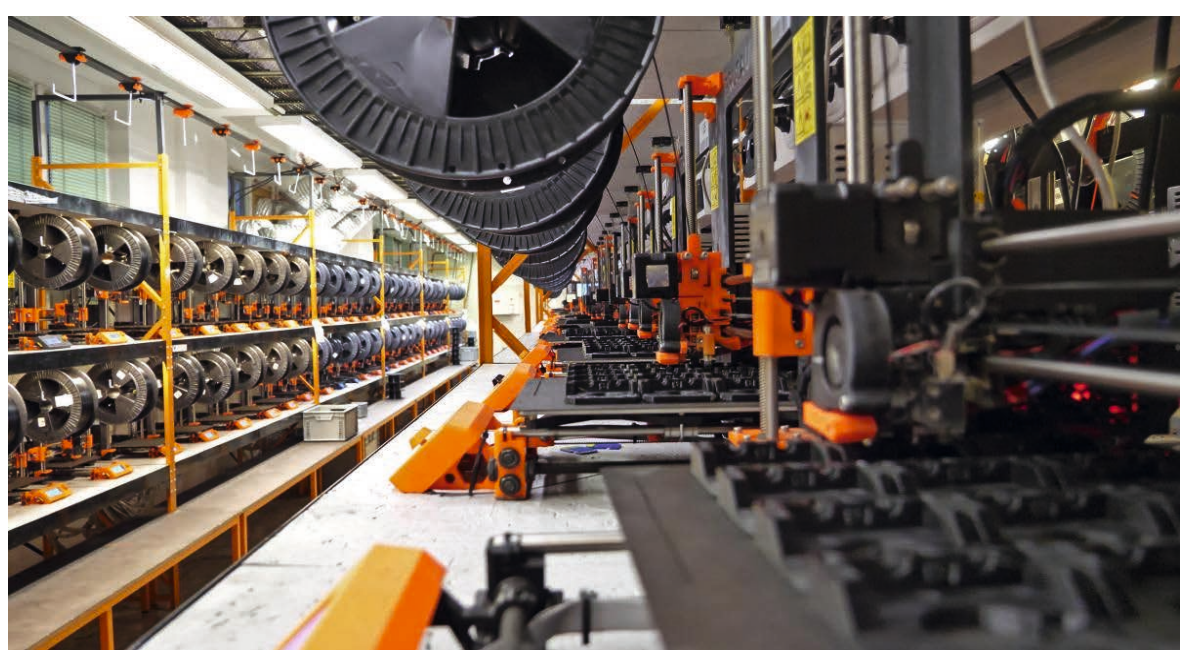

Fig. 2. Farm of the Prusa Research company Copyright permission from Prusa Resarch a.s. Source: Prusa Research (online) 
Fig. 3. Diagram of the application of additive manufacturing in crisis management to support the strategic reserve system (own elaboration)

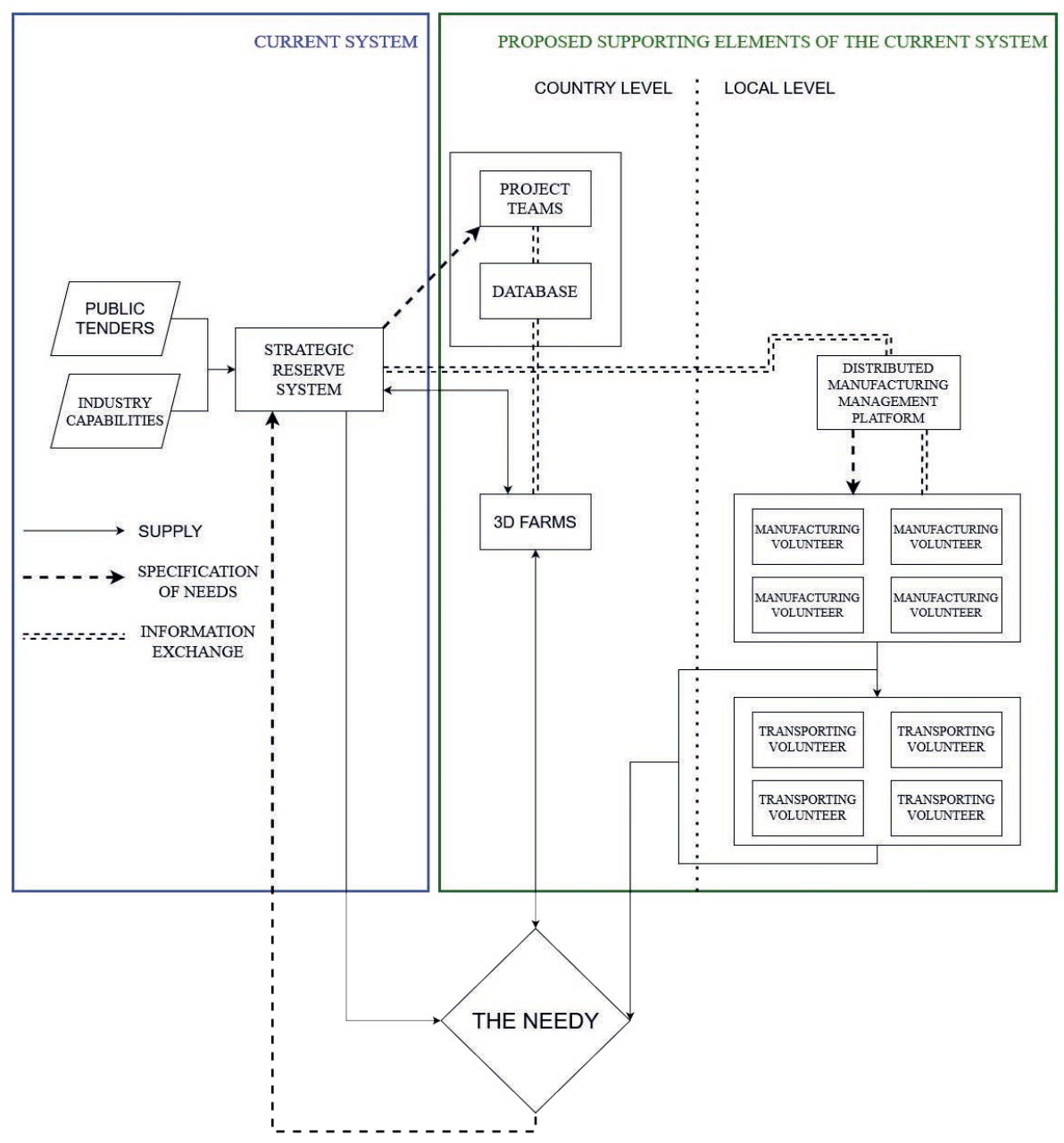

In this model, the project teams would be working on a continuous basis to create, test and legalise their solutions, as well as to develop technical documentation or perform the necessary certification tests. The process of the design of key parts would be based on an analysis of existing crises or those which are predictable, while the experience and skills gained in this manner would prove invaluable in a situations for which the magnitude or causes prevent us from being prepared in advance.

A diagram of such a system is presented in Figure 3. The diagram shows the current state of the art based on a centralised system of strategic reserves and a proposal to support it through the use of 3D printing technology. The idea of exploiting the advantages of additive technologies is based on the formalised possibilities of the national component (managed and prepared in advance) and those of local capabilities represented by volunteers (distributed production). The combination of the current system's capabilities and new complementary components enables the strategic reserve system's capabilities to triple during a crisis. Additionally, by taking into account the potential of local production, the system's sensitivity to logistical disruptions can be reduced. The blockage or disturbance of one supply chain link would not result in a complete lack of equipment or supplies for those in need.

\section{Conclusion}

The system built in accordance with Figure 3 would guarantee the shortest possible response time and flexible reaction to the crisis situation, with a simultaneous significant reduction in costs related to the maintenance 
of material reserves. In addition, it is extremely reliable thanks to the use of the distributed manufacturing model which is capable of operating even in conditions of full isolation. The key factor in relationships organised in the proposed manner is the coordination of activities ensuring efficient production of the desired elements in accordance with the technical documentation, as well as their distribution within the country. Unfortunately, the current legislative status in a number of countries generates legal problems as there are no regulations governing the use of additive technologies (Salmi, et al. 2020).

Let us consider the legal issues using the example of a life-saving device. Should such a device fail, who would be responsible for the malfunction: the designer, the printer manufacturer, the filament manufacturer or the volunteer who manufactured it? Even specifying very strict requirements for materials and printing parameters would not guarantee complete repeatability of manufacturing on different machines, and in particular, those for non-professional use, where drive belts may be too lose, where extruders could be incorrectly calibrated, where the work bed may be uneven or the filament may be wet. The solution could be to manufacture a test model, printed alongside the main model, which would be subject to specific tests, depending on the intended future use. These tests could include verification of the quality of layer adhesion, the correct print tolerance for moving parts or mechanical strength testing.

Present-day threats make us realise that the key factor in avoiding crises or minimising their impact is the response time and proper character of the response, both of which may not always be achieved using the measures currently taken. However, appropriate use of the advantages of additive technologies could improve the operation of the entire crisis management system and serve as a supplementary measure in areas where traditional production is not optimal. 3D printing has enormous potential to preserve human health and save life in crisis situations where the supply chain is limited. It has been proven to work in the fight against the COVID-19 pandemic. However, for large-scale use of additive manufacturing technologies in crisis management, both systemic changes and sturdy legal foundations would be needed as they are necessary to ensure that persons responsible for safety and security would be able to use the entire available manufacturing potential to lessen the repercussions of a crisis. The dynamic development of additive manufacturing is an undeniable fact, and the improvement of techniques and the possibility of manufacturing elements in this manner is way ahead of the legislative regulations.

\section{Discussion}

Thus far, there have been no known official solutions for the use of 3D printing technology in crisis management systems, especially within the strategic reserves system. However, it has been acknowledged that both the EU and NATO (Mendis, et al. 2020) have started work on defining the principles and possibilities of $3 \mathrm{D}$ printing for the needs of the military in various situations, including responses to natural disasters. The concept of using centralised solutions in the form of 3D farms is relatively easy to implement and authorise within the legal framework. However, the most urgent issue to be tackled in the near future is the establishment of a proper statutory basis enabling both the legal and the effective use of distributed manufacturing. An extra challenge would be to create national or even international standards enabling crossborder cooperation to manage the quality of manufactured elements.

One possibility could be the initiative of the European Commission called the Disaster Risk Management Knowledge Centre, or DRMKC, which combines several departments of the European Commission, Member States and other bodies such as the Emergency Response Coordination Centre (ERCC), which coordinates the delivery of assistance to disaster-stricken countries, such as relief items, expertise, civil protection teams and dedicated equipment. One of the 
roles of the DRMKC is to assess the current state of disaster risk management science and technology in Europe, address technological and operational challenges to cover the existing gaps, and assist in building common standards.

In order to achieve this, a science advisory panel of experts and scientists at local, national and European levels provides analyses, updates and advice into research and innovation needs in disaster risk management. Additionally, a common repository of relevant research and operational projects and results, set up through the DRMKC and its Web-platform, could help share lessons learnt.

The DRMKC could be the vehicle to assess both the technical and the nontechnical challenges of using 3D printing technologies in crisis situations.

\section{References}

3D Printing Market Size, Share \& Trends Analysis Report (2020). Grand View Research.

Akcja Drukarze Dla Szpitali (online). https://www.drukarzedlaszpitali.pl/ (online: 24.04.2020).

ARME (online). https://armeevent.com/ (online: 24.04.2020).

Bogdanowicz, K.A., Pirone, D., Prats-Reig, J., Ambrogi, V., Reina, J.A., Giamberini, M. (2018). In Situ Raman Spectroscopy as a Tool for Structural Insight into Cation Non-Ionomeric Polymer Interactions during Ion Transport. Polymers, 10, 416.

Bogdanowicz, K.A., Maleczek, S., Drabczyk, K., Iwan, A. (2020). Engineering Concept of Energy Storage Systems Based on New Type of Silicon Photovoltaic Module and Lithium Ion Batteries. Energies, 13, 3701.

Budd, L., Griggs, S., Howarth, D., \& Ison, S., (2011). A Fiasco of Volcanic Proportions Eyjafjallajökull and the Closure of European Airspace. Mobilities, 6, 31-40.

Cloudhury, K.D., Saha, S., Das, M. (2011). An inventory model with Lot Size Dependent carrying/holding cost. Assam Univ. J. Sci. Technol. Phys. Sci. Technol.,7, 133-136.

Dz. U. 2007 nr 89 poz. 590, Ustawa z dnia 26 kwietnia 2007 r. o zarządzaniu kryzysowym.

Erbeyoglu, G., Bilge, Ü. (2020). A robust disaster preparedness model for effective and fair disaster response. Eur. J. Oper. Res., 280, 479-494.

Farahani, R., Lotfi, M.M., Atefeh, Baghaian, R. Ruiz, Rezapour S. (2020). Mass casualty management in disaster scene: A systematic review of OR \& MS research in humanitarian operations. Eur. J. Oper. Res., 287, 787-819.

Fernandez-Vicente, M., Escario Chust, A., Conejero, A. (2017). Low cost digital fabrication approach for thumb orthoses. Rapid Prototyping Journal, 23, 1020-1031.

Interview with Ford Motor Company CEO for Reuters (online). http://www. reuters.com/article/us-health-coronavirus-usa-fo.rd-motor/ford-geto-produce-50000-ventilators-in-100-days-idUSKBN21H39F (online: 24.04.2020).

Kashte, S., Maras, J.S., Kadam, S. (2018). Bioinspired Engineering for Liver Tissue Regeneration and Development of Bioartificial Liver: A Review. Crit Rev Biomed Eng, 46(5), 413-427. doi:10.1615/ CritRevBiomedEng.2018028276.

Kim, E., Shin, Y.-J., Ahn, S.-H. (2016), The effects of moisture and temperature on the mechanical properties of additive manufacturing components: fused deposition modelling. Rapid Prototyping Journal, 22(6), 887-894. https://doi.org/10.1108/RPJ-08-2015-0095

Krishnaswamy, J.A., Buroni, F.C., Melnik, R., Rodriguez-Tembleque, L., Saez, A. (2020). Design of polymeric auxetic matrices for improved mechanical coupling in lead-free piezocomposites, Smart Materials and Structures, 29(5), art. no. 054002. 
LEITIAT (online), https://covid-leitat.org/en/ventilator/ (online: 24.04.2020).

Levin, D., Mackensen, G.B., Reisman, M., McCabe, J.M., Dvir, D., Ripley, B. (2020). 3D Printing Applications for Transcatheter Aortic Valve Replacement. Curr Cardiol Rep., 22(4), 23.. doi:10.1007/s11886-020-1276-8.

Made in Space (online) https://madeinspace.us/about/spaceflight-missions/ (online: 27.08.2020).

Mendis, D., Nordemann, J.B., Ballardini, R.M., Brorsen, H., Moreno, M., Robson, J., Dickens, P., (2020). The Intellectual Property Implications of the Development of Industrial 3D Printing, Study commissioned to Bournemouth University carried out for the European Commission, Final Report, 12 February 2020.

Minguella-Canela, J., Morales Planas, S., Gomà Ayats, J.R., De los Santos López, M.A., (2018). Assessment of the Potential Economic Impact of the Use of AM Technologies in the Cost Levels of Manufacturing and Stocking of Spare Part Products. Materials, 11, 1429.

Prusa Research (online). https://blog.prusaprinters.org/from-design-to-mass3d-printing-of-medical-shields-in-three-days/ (online: 24.04.2020).

Raport dotyczący rozwoju rynku drukarek 3D (online). https://www2. deloitte.com/content/dam/Deloitte/pl/Images/Infografiki/infografika_ zortrax_3d_printing_market_outlook_pl.pdf (online: 24.04.2020).

Salmi, M., Akmal, J.S., Pei, E., Wolff, J., Jaribion, A., Khajavi, S.H. (2020). 3D Printing in COVID-19: Productivity Estimation of the Most Promising Open Source Solutions in Emergency Situations. Appl. Sci., 10, 4004.

Snopczyński, M., Kotliński, J., Musiatek, I. (2019). Badanie wtaściwości mechanicznych materiatów stosowanych w technologii FDM. Mechanik, 4, https://doi.org/10.17814/mechanik.2019.4.37

Sun, J., Zhou, W., Huang, D., Yan, L. (2018). 3D Food Printing: Perspectives. In: T. Gutiérrez (ed.) Polymers for Food Applications. Springer, Cham. https://doi. org/10.1007/978-3-319-94625-2_26.

Tian, X., Liu, T., Wang, Q., Dilmurat, A., Li, D., Ziegmann, G. (2017). Recycling and remanufacturing of 3D printed continuous carbon fiber reinforced PLA composites. Journal of Cleaner Production, 142, 1609-1618.

VentilAid (online). https://www.ventilai.org/pl/ (online: 24.04.2020).

Wimpenny, D.I., Pandey, P.M, Kumar L.J. (2017). Advances in 3D Printing\& Additive Manufacturing Technologies, Singapore: Springer Science+Business Media. 


\section{Analiza możliwości zastosowania technologii druku 3D w sytuacjach kryzysowych}

\section{Streszczenie}

Zdarzenia związane ze zmianami klimatu i nasileniem się naturalnych kataklizmów oraz częstszym występowaniem nowych chorób spowodowała wzrost znaczenia bezpieczeństwa regionalnego oraz zarządzania kryzysowego na całym świecie. Pomocny w tej kwestii może okazać się wydruk trójwymiarowy, który w ostatnich latach znacząco się rozwinął zarówno pod względem parametrów wydruku jak i wielkości potencjatu produkcyjnego. Stwarza to olbrzymie możliwości, które odpowiednio pokierowane mogą ratować życie i zdrowie w sytuacjach kryzysowych, gdy klasyczne tańcuchy dostaw zostają zaburzone lub wręcz przerwane. Wykorzystywanie technologii przyrostowych posiada jednak swoje ograniczenia i by móc wykorzystać w petni oferowane przez nie możliwości, należy stworzyć i osadzić prawnie funkcjonalny system do wsparcia zarządzania kryzysowego. Niniejsza praca skupia się na pokazaniu wad oraz zalet wykorzystania drukarek 3D oraz możliwości ich implementacji do obecnych systemów przeciwkryzysowych. W artykule został zaproponowany model włączenia technologii przyrostowych do systemu zarządzania kryzysowego.

Stowa kluczowe: druk trójwymiarowy, farmy 3D, produkcja rozproszona, technologie przyrostowe, COVID-19 